\title{
Role of miRNA-19a in Cancer Diagnosis and Poor Prognosis
}

\author{
Alessio Ardizzone ${ }^{1}$, Giovanna Calabrese ${ }^{1}\left(\mathbb{D}\right.$, Michela Campolo $^{1}$, Alessia Filippone ${ }^{1}$, Dario Giuffrida ${ }^{2}$, \\ Francesca Esposito $^{3}$, Cristina Colarossi ${ }^{2}$, Salvatore Cuzzocrea ${ }^{1}$ (D) Emanuela Esposito ${ }^{1, * \mathbb{D}}$ and Irene Paterniti ${ }^{1}$ \\ 1 Department of Chemical, Biological, Pharmaceutical and Environmental Sciences, University of Messina, \\ Viale Ferdinando Stagno D’Alcontres, 98166 Messina, Italy; aleardizzone@unime.it (A.A.); \\ gcalabrese@unime.it (G.C.); campolom@unime.it (M.C.); alessia.filippone@unime.it (A.F.); \\ salvator@unime.it (S.C.); ipaterniti@unime.it (I.P.) \\ 2 Istituto Oncologico del Mediterraneo, Via Penninazzo 7, 95029 Viagrande, Italy; \\ dario.giuffrida@grupposamed.com (D.G.); cristina.colarossi@grupposamed.com (C.C.) \\ 3 IOM Ricerca Srl, Via Penninazzo 11, 95029 Viagrande, Italy; francesca.esposito@grupposamed.com \\ * Correspondence: eesposito@unime.it; Tel.: +39-090-676-5208
}

check for updates

Citation: Ardizzone, A.; Calabrese,

G.; Campolo, M.; Filippone, A.;

Giuffrida, D.; Esposito, F.; Colarossi,

C.; Cuzzocrea, S.; Esposito, E.;

Paterniti, I. Role of miRNA-19a in Cancer Diagnosis and Poor Prognosis. Int. J. Mol. Sci. 2021, 22, 4697. https://doi.org/10.3390/ijms22094697

Academic Editors: Daniela Grimm and Michele Caraglia

Received: 26 March 2021

Accepted: 27 April 2021

Published: 29 April 2021

Publisher's Note: MDPI stays neutral with regard to jurisdictional claims in published maps and institutional affiliations.

Copyright: (C) 2021 by the authors. Licensee MDPI, Basel, Switzerland. This article is an open access article distributed under the terms and conditions of the Creative Commons Attribution (CC BY) license (https:// creativecommons.org/licenses/by/ $4.0 /)$.

\begin{abstract}
Cancer is a multifactorial disease that affects millions of people every year and is one of the most common causes of death in the world. The high mortality rate is very often linked to late diagnosis; in fact, nowadays there are a lack of efficient and specific markers for the early diagnosis and prognosis of cancer. In recent years, the discovery of new diagnostic markers, including microRNAs (miRNAs), has been an important turning point for cancer research. miRNAs are small, endogenous, non-coding RNAs that regulate gene expression. Compelling evidence has showed that many miRNAs are aberrantly expressed in human carcinomas and can act with either tumorpromoting or tumor-suppressing functions. miR-19a is one of the most investigated miRNAs, whose dysregulated expression is involved in different types of tumors and has been potentially associated with the prognosis of cancer patients. The aim of this review is to investigate the role of miR-19a in cancer, highlighting its involvement in cell proliferation, cell growth, cell death, tissue invasion and migration, as well as in angiogenesis. On these bases, miR-19a could prove to be truly useful as a potential diagnostic, prognostic, and therapeutic marker.
\end{abstract}

Keywords: cancer; miRNAs; miR-19a; tumor suppressors; oncogene; diagnostic and prognostic markers; poor prognosis; miR-19a therapeutic value

\section{Introduction}

Cancer is one of the most common diseases affecting millions of people worldwide every year, representing the second leading cause of mortality after cardiovascular disease [1]. Uncontrolled cell growth due to genetic alterations [2], environmental factors [3] such as smoking [4], incorrect diet [5], obesity [6], infections [7], ionizing radiation [8], stress [9] and environmental pollutants [10] are the common denominators of each type of neoplasm. Especially, genetic alterations, which include chromosomal abnormalities and genetic mutations, represent one of the most noticeable causes [11] that contribute to tumorigenesis, affecting cell growth and metastases development [12].

Currently, although many conventional and innovative therapies are a valuable aid in the fight against cancer, the mortality rate remains high; in this context, late diagnosis represents one of the unfavorable factors [13]. Therefore, it is assumed that a precise and accurate search for diagnostic biomarkers can represent a turning point for cancer treatment by decreasing the poor prognosis in patients [14].

In the last decade, the diagnostic, prognostic, and therapeutic properties of microRNAs (miRNAs) have been investigated in many cancer types [15]. In fact, much evidence has demonstrated that miRNAs play important roles in tumorigenesis, development, and clinical therapy by acting as oncogenes or tumor-suppressor genes in various cellular processes such as tumor proliferation, apoptosis, angiogenesis, invasion, and metastasis [16]. 
Molecularly, miRNAs are small, endogenous, single-stranded, non-coding RNA molecules, approximately 20-22 nucleotides in length that originate from a stem-loop precursor [17].

The synthesis of mature miRNAs is a process that begins in the cell nucleus and completes in the cytoplasm, also involving highly specific enzymes [18]. Most miRNAs are transcribed by the RNA polymerase II complex, or to a lesser extent by RNA polymerase III [19], in a long primary polyadenylated transcript called pri-miRNA (100-1000 nt). The monocistronic pri-miRNA comprises a 7-methylguanosine cap at the $5^{\prime}$ end and a poly (A) tail at the $3^{\prime}$ end folded into a hairpin secondary structure consisting of a doublestranded stem, a erminal loop and two single-stranded segments parallel to the $3^{\prime}$ and $5^{\prime}$ ends [18]. The pri-miRNA, inside the cell nucleus, is split into smaller molecules (about 70-80 nucleotides), called pre-miRNA, from a very specific complex composed of the enzymes DGCR8 and Drosha (type III RNA-ase). The cut made by DGCR8 must be very precise to ensure the affinity of the miRNA for the target mRNA [18]. Successively, the pre-miRNA is transported into the cytosol by Exportin-5 protein (nucleus-cytoplasmic transporter) and Ran-Guanosine Triphosphate (Ran-GTP) cofactor and further cleaved by Dicer (type III RNase) [18] in a mature, short, double-stranded RNA (dsRNA) of about $22 \mathrm{nt}$. The dsRNA is bound by the Argonauta protein (Ago) and incorporated into the enzymatic complex called RISC (RNA-induced silencing complex), as a mature miRNA exercising its biological function [18].

miRNAs induce gene silencing by overlapping complementary sequences present on mRNA molecules; this overlap involves the repression of messenger translation and its degradation [20]. The silencing operated by an miRNA can occur through several mechanisms which may include the cleavage of the RNA molecule, or the destabilization of the RNA molecule by reducing the length of the polyA tail, or the decrease in the translation efficiency of the RNA molecule [21].

Most human miRNAs reside in the introns of genes or noncoding mRNA transcript regions [22], while other miRNAs are found within $3^{\prime}$ UTRs of mRNA genes, exons of noncoding mRNA genes, or are clustered with other miRNA genes [23]. miRNAs are evolutionarily conserved from worms to humans, and on the basis of the sequence homology at the $5^{\prime}$ end of the mature miRNAs can be clustered into families. A single miRNA can regulate as many as 200 gene targets different in their function, such as transcription factors, secreted factors, receptors, and transporters [24].

Thus, miRNAs form a complex monitoring network which, by negatively regulating the expression of their target genes at the post-transcriptional level, can control a wide variety of physiological functions [25].

Precisely for these properties, miRNAs have aroused considerable interest as prognostic markers and therapeutic targets for human neoplasms [26].

The members of the miR-19 family have identical seed regions and arise from two different paralogous clusters, miR-17-92 (miR-19a and miR-19b-1) and miR-106a-363 (miR19-b-2) [27].

The miR-19 family plays an important role in regulating and maintaining tissue homeostasis and the normal development of organisms [27,28]. It has also been found that the miR-19 family contributes to the homeostatic maintenance of the immune system, specifically lymphocytes, the regulation of the differentiation of follicular helper T cells [29], and the modulation of the development of B cells [30]. Some evidence suggests that the miR-19 family is implicated in regulating inflammation, tissue fibrosis, aging, metabolism, and tumorigenesis [27].

Moreover, members of the miR-19 family contribute to regulating the development of the nervous system, respiratory systems, cardiovascular systems, blood vessel formation, vertebrate axis, etc. Accordingly, their dysregulation often results in various diseases, and even cancer [27].

Among miR-19 family members, miR-19a is the most well-known oncogenic miRNA [31], and its oncogenic activity results in promoting c-MYC-induced lymphomagenesis by re- 
pressing apoptosis and the tumor suppressor phosphatase and tensin homolog (PTEN) [31]. Furthermore, miR-19a activates the protein kinase B (AKT)-mammalian target of rapamycin (mTOR) pathway, thereby functionally antagonizing PTEN to promote cell survival [31].

PTEN targeted by miR-19a [32], and more specifically of PTEN/AKT signaling [33,34], also induces tumor cells' resistance to chemotherapeutic agents. Chemoresistance is the primary cause of treatment failure in cancer patients [35] and it is attributed to various aspects, including diminished drug accumulation and drug-target interaction, increased tumor stem cell populations and autophagic activity, and reduced apoptotic processes in cancer cells [35].

miR-19a has been shown to alter cellular sensitivity to chemotherapy drugs, including the well-known cisplatin, 5-Fluorouracil and Adriamycin, and to upregulate the expression of P-glycoprotein (P-gp), critical in the management of cytotoxic drug efflux [36].

Therefore, it is also clear that in this circumstance, the control of miR-19a levels could contribute to positive outcomes for cancer patients.

Moreover, several studies have identified thousands of circular RNAs (circRNAs) in various organisms, denoting their importance in various pathophysiological processes [37]. Indeed, circRNAs have the ability to regulate gene expression by affecting transcription, mRNA turnover, and also translation by sponging RNA-binding proteins and miRNAs [37].

Consequently, given the wide correlation between circRNAs on miRNA activity, several studies, especially in the oncology field, have investigated the impact of miRNA sponging by circRNA on gene regulation [38,39]. In this context, innovative methods for its molecular detection can play a key role in multiple identifications and data correlation, providing important oncology research advancements.

Hence, it is established that miR-19a is involved in some processes such as carcinogenesis, tumor progression, and chemoresistance by the modulation of several signaling pathways. Therefore, based on all the evidence previously presented, this review aims to summarize the current status and knowledge of the predictive role of miR-19a in different types of cancer and its potential clinical relevance for cancer diagnosis and prognosis.

\section{Roles and Mechanisms of Action of miR-19a in Clinical Cancer Features}

Recently, scientific evidence has indicated the dysregulation of miRNAs in cancer initiation, progression, and aggressiveness, thus affecting the clinical features of cancer patients.

On this basis, we focused on miR-19a, probing its molecular mechanisms and analyzing its key role in different tumor types.

Several studies have shown that aberrantly expressed miRNAs contribute to the initiation and progression of brain tumors; between these, miR-19a has a central role.

Qin et al. [40] showed that the upregulation of miR-19a-3p promoted cell proliferation, migration, and invasion by repressing the expression of PTEN, as reported in Table 1. PTEN is one of the most frequently mutated tumor suppressor genes [41] in human cancers that plays a key role in tumor cell growth, survival, and metabolic regulation. Functionally, PTEN acts as a negative regulator of cell survival and protein synthesis via inhibition of the phosphatidylinositol 3-kinase (PI3K) / AKT [41], one of the most important molecular pathways involved both in cell survival and in malignant neoplasms, which contributes, if altered or deregulated, to tumor pathogenesis [42] and chemoresistance [43].

On other hand, Chen et al. [44] also reported that miR-19a-3p overexpression promotes cell proliferation and invasion by targeting RhoB in glioma, while its inhibition suppresses them, suggesting that miR-19a may act as an oncogene in gliomas.

The link between the Rho family and miR-19a-3p is also elucidated by Lv et al. [45]. In their study, the authors identified the existence of a circ-EPB41L5/miR-19a/EPB41L5/RhoC/AKT regulatory axis. Circ-EPB41L5 inhibits the proliferation, migration, and invasion of glioma cells by sponging miR-19a-3p and regulating the host gene EPB41L5 expression, which reduces the progression of glioma by inhibiting RhoC and p-AKT.

RhoC upregulation is associated with cell proliferation, contributing to the epithelialmesenchymal transition (EMT). In addition, RhoC improves cell motility, which conse- 
quently results in a greater ability of the tumor to become invasive [46]. It is known that there is a connection between the increase in $R h o C$ expression and an advanced stage of the tumor as well as with the presence of metastases [47]; to which certain crosstalk with angiogenic factors such as vascular endothelial growth factor (VEGF) also contributes [48].

Downregulation of miR-19a in gliomas plays an anti-oncogenic role, which suggests its potential application as a target for gene therapy. Furthermore, because its overexpression is often associated with a poor prognosis, it could represent a new diagnostic and prognostic marker for gliomas.

Xu et al. [49] investigated the impact of miR-19a-3p/miR-19b-3p on clinicopathologic factors and the prognosis of patients with ESCC. They observed that miR-19b-3p expression was positively correlated with tumor size, lymph node metastasis, and clinical stage, while $\mathrm{miR}-19 \mathrm{a}-3 \mathrm{p}$ is a prognostic indicator for progression-free survival and overall survival.

Similar results were obtained from Plum et al. [50]. They demonstrated that upregulation of miR-19a/b is associated with tumor progression and the occurrence of lymph node metastasis in human esophageal adenocarcinoma, indicating that miR-19a/b could represent a new prognostic biomarker in this cancer form.

Many studies [51-53] have shown that miR-19a is involved in the proliferation of human gastric cancer (GC). Yuan et al. [51] demonstrated that miR-17-92a-1 Cluster Host Gene (MIR17HG)-derived miR-18a and miR-19a-3p coordinately mediate GC cell metastasis by directly inhibiting mothers against decapentaplegic homolog 2 (SMAD2) expression and upregulating Wingless-related integration site (Wnt)/ $\beta$-catenin signaling.

Qin et al. demonstrated that the suppressor of cytokine signaling 1 (SOCS1) is a novel target of miR-19a-3p in GC cells. They reported that miR-19a-3p expression is inversely correlated with SOCS1 expression in GC cells, and that its overexpression markedly promotes proliferation and tumorigenicity both in vitro and in vivo [54]. In accordance with this evidence, other studies $[55,56]$ have confirmed miR-19a overexpression in GC patients, suggesting that miR-19a could represent a potential new diagnostic biomarker for GC.

Liu et al. [57] demonstrated that miR-19a-3p is involved in colorectal cancer, promoting its proliferation and migration by targeting $\mathrm{T}$ cell Intracellular Antigen 1 (TIA1), thus also suggesting miR-19a as a new diagnostic and prognostic biomarker for gastrointestinal cancers.

The role of miR-19a-5p in hepatocellular carcinoma (HCC) has also been elucidated by Baik et al. [58], who showed that the suppression of adenine nucleotide translocase 2 (ANT2) by short hairpin RNA (shRNA) downregulates miR-19a through the PI3K/Akt pathway. The knockdown of ANT2 directly downregulates miR-19a, thus resulting in the suppression of tumor growth in HCC cells and clinical samples.

Tan et al. [59] demonstrated that high levels of miR-19a-5p correlate with poor prognosis in patients, proposing that miR-19a is a potential therapeutic target for pancreatic cancer.

Recently, it has been revealed that PLGF influences miR-19a-3p expression by modulating c-MYC [60]. Furthermore, a positive pairwise correlation among PLGF, c-MYC, and miR-19a expression in gallbladder cancer (GBC) tissues has been displayed [60]; this finding confirmed that the PLGF/c-MYC/miR-19a axis is involved in tumor progression of the gastrointestinal tract.

The upregulated expression of miR-19a-3p has also been determined in clinical tongue squamous cell carcinoma cells (TSCC) specimens [61].

Wu et al. [62] reported that miR-19a-3p is upregulated in laryngeal squamous cell carcinoma (LSCC) patients and is correlated with neck nodal metastasis, poor differentiation, and advanced stage, indicating that its overexpression is associated with reduced overall survival. It has also been demonstrated that miR-19a plays an influent effect in laryngeal verrucous squamous cell carcinoma (LVSCC), a highly differentiated form of LSCC. Marioni et al. [63] reported that miR-19a expression is significantly higher in malignant glottic lesions (LSCC and LVSCC) than in benign ones. Thus, these studies indicate the oncogenic role of miR-19a in the progression of LSCC and denote it as a possible biomarker to establish an earlier diagnosis as well as a marker of differentiation in the various forms of laryngeal tumors. 
miR-19a overexpression is involved in the pathophysiology of lung cancer, and is associated with the poor prognosis, metastasis, and proliferation of pulmonary cancer cells [64]; thus, it constitutes a good biomarker and a possible target therapy for lung tumors [65].

Gu et al. [66] demonstrated that miR-19a-3p/miR-19b-3p promotes the proliferation and migration of lung cancer cells by targeting Microtubule-Associated Scaffold Protein 1 (MTUS1). Following these suggestions, miR-19a could represent an important diagnostic and prognostic marker for differential diagnoses of lung cancers [67].

Some clinical studies $[68,69]$ have shown that high levels of miR-19a are implicated in a more frequently large tumor size, advanced clinical stage, positive distant metastasis, and poor response to chemotherapy in osteosarcoma patients. Huang et al. [70] and Zou et al. [71] described that miR-19a-5p and miR-19a-3p overexpression contributes to both the risk of poor prognosis in osteosarcoma and the probability of developing metastases, respectively.

miRNAs profiling can also be useful for the characterization and classification of different thyroid carcinomas, as well as in strengthening therapeutic strategies.

Calabrese et al. [72] showed that miR-19a-3p overexpression is correlated with a poor prognosis of thyroid cancers, highlighting its contribution to more de-differentiation and aggressiveness.

These results suggest that not only does miR-19a-3p have an important role in the malignancy of thyroid cancers [73], but it also represents an important prognostic indicator and is a good therapeutic target [74] for anaplastic thyroid carcinoma (ATC) patients.

The role of miR-19a has also been investigated in clear cell renal cell carcinoma (ccRCC) tissues and human cell lines, highlighting that the high expression of miR-19a-3p is correlated with poor prognosis via promoting cell proliferation and suppressing PTEN/mothers against decapentaplegic homolog 4 (SMAD4) expression [75]. In addition, Niu et al. [76] indicated that miR-19a-3p directly targets the $3^{\prime}$ untranslated region ( $\left.3^{\prime} U T R\right)$ of RhoB, promoting tumorigenesis, cancer cell proliferation, and invasiveness, and suggesting the clinical potential of miR-19a as a molecular target in ccRCC. Ge et al. [77] assessed the relationship of high miR-19a levels with the progression and prognosis of chromophobe renal cell carcinoma (chRCC), demonstrating that miR-19a inhibition is significantly associated with both recurrence-free survival and overall survival.

miR-19a upregulation has also been correlated with bladder cancer prognosis. The role of the PI3K/AKT pathway and its crosstalk with miR-19a-3p in bladder carcinogenesis has also been elucidated by Calderaro et al. [78], thus opening the way to involvements between miR-19a and various molecular patterns in bladder urothelial carcinomas (UCs).

Mearini et al. [79] reported that miR-19a-3p is overexpressed in bladder cancer carcinogenesis and its oncogenic role is dependent on targeting PTEN [80] as well as inhibiting the expression of RhoB, in order to promote the invasion and EMT of bladder cancer cells [81]. Furthermore, it has been shown that miR-19a overexpression is associated with the poor prognosis of bladder cancer patients [82], representing a good starting point for future preclinical and clinical exploration.

Despite the initial controversy over the beneficial role of miR-19a in prostate cancer [83], recent studies are consistent in indicating its crucial role in prostate tumorigenesis and progression [84]. Its involvement includes the promotion of cell migration, invasion, and EMT in prostate cancer by directly binding to Cullin-5 (CUL5) mRNA $3^{\prime}$-UTR as reported by Wang et al. [85]; the regulation of proliferation and apoptosis of prostate cancer cells by targeting the B cell translocation gene 1 (BTG1) as described by Lu et al. [86], and the inhibition of vacuolar protein sorting-associated protein 37A (VPS37A) expression, as indicated by Fu et al. [87].

All these data highlight the importance of miR-19a for the development of new targeted therapies and suggest its use as a prognostic biomarker in prostate cancer patients [88]. 
miR-19a overexpression promotes cell proliferation, metastasis, migration, invasion, and angiogenesis in breast cancer (BC) [89]. Sochor et al. [90] developed and validated a composite risk score based on the expression of three miRNAs, including miR-19a, with prognostic value for BC. They reported that miR-19a overexpression is correlated specifically with bone metastasis, suggesting that it could be a good diagnostic and prognostic marker for BC. Additionally, Kawaguchi et al. [91] showed that miR-19a overexpression is correlated with poor prognosis and the risk of multiple metastases, as well as angiogenesis and EMT.

Alunni-Fabbroni et al. [92] indicated that miR-19a-3p shows a promising role differentiating early BC patients at different time points and from healthy controls. In addition, the regulation of miR-19a in $\mathrm{BC}$ is also useful in managing chemoresistance, as suggested by Liang et al. [32]. Ouchida et al. [93] suggested that inosine monophosphate dehydrogenase 1 (IMPDH1) and probable aminopeptidase-like 1 (NPEPL1) genes are direct targets of miR-19a in BC, while the exogenous expression of these genes is not associated with the growth suppression of MCF-7 cells. Hence, once again, the importance and usefulness of miR-19a both as a diagnostic biomarker and as a molecular target are highlighted.

Scientific findings have confirmed the involvement of miR-19a in malignant lymphoma, elucidating its crucial roles in the tumorigenesis and pathogenesis of aggressive transformed, high-grade, and refractory lymphomas, highlighting its prognostic role [94].

Lv et al. [95] performed bioinformatic analyses and demonstrated that 41 target genes of miR-19a are associated with the development and progression of multiple myeloma (MM), suggesting its potential role as a biomarker. Another study [96] also confirmed that miR-19a-3p plays the role of an oncogene by regulating the PTEN/AKT/pAKT pathway in $\mathrm{MM}$ and promoting cell proliferation and inhibiting apoptosis.

Wang et al. [97] demonstrated that miR-19a-3p is highly expressed in ovarian cancer tissues and cell lines and that its overexpression promotes proliferation, while its downregulation reduces the growth of ovarian cancer cells. Furthermore, in this study, the authors suggested that the overexpression of PTEN suppresses miR-19a, promoting an effect on cancer cell growth, indicating that miR-19a expression and PTEN are inversely related in ovarian cancer tissues. The role of miR-19a has also been investigated in metastatic serous ovarian cancer (SOC). In fact, Wahab et al. [98] described a significant differential expression of 48 miRNAs, including miR-19a, in metastatic SOC compared to healthy subjects. These studies proved a potential oncogenic role of miR-19a in ovarian cancer, suggesting that it could represent a promising marker for ovarian cancer diagnosis, prognosis, and treatment.

The role of miRNAs in cervical cancer concerns many aspects of tumor cell development and survival, including sensitivity to radiotherapy.

In their study, Wang et al. [99] showed that the silencing of miR-19a-5p significantly improved the sensitivity of SiHa cells to radiotherapy by reducing proliferation, increasing apoptosis, upregulating BCL2-associated X (BAX), and downregulating B cell lymphoma 2 (Bcl-2) [99].

Similar results have been shown by $\mathrm{Xu}$ et al. [100], who demonstrated that both miR-19a-5p and miR-19b-5p are vastly expressed in human cervical cancer cells and are implicated in malignant HeLa and C33A cell phenotypes [100].

In addition, miR-19a-5p and miR-19b-5p have also been shown to control CUL5 levels directly and negatively in cervical cancer cells, both emphasizing their importance and that of their target genes in tumorigenesis processes [100].

Furthermore, it is interesting to highlight the Bcl-2 interacting mediator of cell death (BIM), an initiator of the intrinsic apoptotic pathway in both physiological and pathophysiological conditions [101]. In fact, its reduction has often been associated with tumor promotion, while its overexpression has the ability to inhibit tumor growth and resistance to chemotherapy [102]. Therefore, BIM has emerged as a key mediator in the regulation of tumorigenesis, as demonstrated by several studies $[103,104]$ that indicate it as a promising target in the field of anticancer therapy. In particular, the miR-17-92 cluster has been 
found to suppress BIM expression in multiple myeloma cells [105], human ovarian cancer cells [106], and esophageal adenocarcinoma [102]. miR-19a, as a prominent component of the miR-17-92 cluster, can facilitate tumor formation, inhibiting BIM expression and promoting the proliferation of tumor cells [107]. The function of BIM, along with all other miR-19a targets described in this review, is shown in Figure 1.

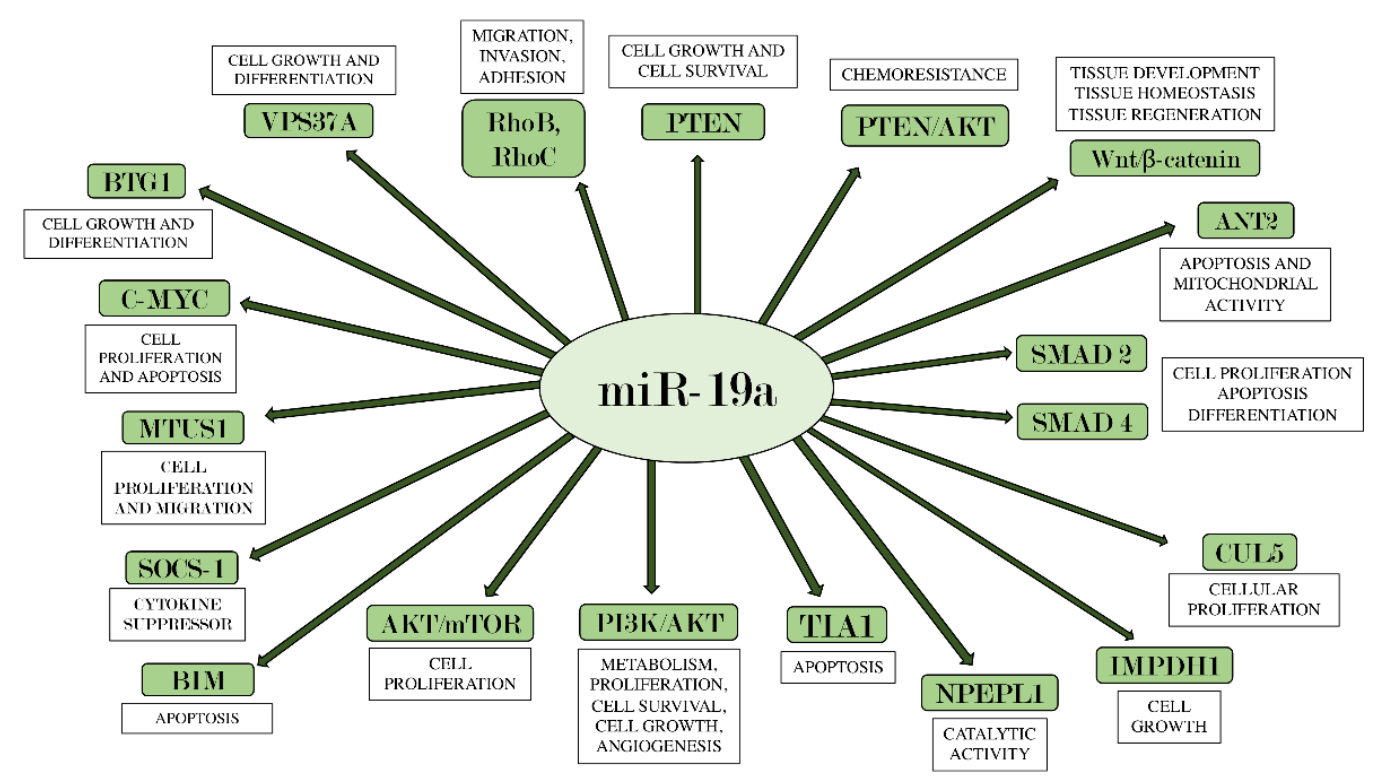

Figure 1. miR-19a and its main target genes. The figure summarizes the interactions between miR-19a and the target genes on which it acts, also indicating each their main biological effects.

Table 1. This table summarizes the relationship between the miR-19a isoform and its target genes in several types of cancers.

\begin{tabular}{|c|c|c|c|c|}
\hline Tumor Type & Isoform of miR-19 & Type of Study & Target Genes & Reference \\
\hline \multirow{3}{*}{ Gliomas } & miR-19a & in vitro and clinical & PTEN & [40] \\
\hline & miR-19a & in vitro and clinical & RhoB & [44] \\
\hline & miR-19a & in vitro, in vivo, and clinical & EPB41L5, RhoC, p-AKT & [45] \\
\hline \multirow{2}{*}{ GC } & miR-19a & in vitro, in vivo, and clinical & $\begin{array}{c}\text { SMAD2, } \\
\text { Wnt/b-catenin }\end{array}$ & [51] \\
\hline & miR-19a & in vitro, in vivo, and clinical & CUL5 & [52] \\
\hline Colorectal & miR-19a & in vitro and clinical & TIA1 & [57] \\
\hline \multirow{2}{*}{$\mathrm{HCC}$} & miR-19a & in vitro & PTEN/Akt & [108] \\
\hline & $\operatorname{miR}-19 a$ & in vitro & PI3K/Akt & [58] \\
\hline Pancreatic & $\operatorname{miR}-19 a$ & in vitro, in vivo, and clinical & RhoB & [59] \\
\hline LVSCC & miR-19a & clinical & SOCS-1 & [63] \\
\hline Lung & $\mathrm{miR}-19 \mathrm{a} / \mathrm{b}$ & in vitro and clinical & MTUS1 & [66] \\
\hline \multirow{2}{*}{ Osteosarcoma } & miR-19a & in vitro, in vivo, and clinical & RhoB & [109] \\
\hline & miR-19a & in vitro and clinical & PTEN & {$[110,111]$} \\
\hline \multirow{2}{*}{ ccRCC } & miR-19a & in vitro and clinical & PTEN/SMAD4 & [75] \\
\hline & miR-19a & in vitro and clinical & RhoB & [76] \\
\hline
\end{tabular}


Table 1. Cont.

\begin{tabular}{|c|c|c|c|c|}
\hline Tumor Type & Isoform of miR-19 & Type of Study & Target Genes & Reference \\
\hline \multirow{4}{*}{ Bladder } & miR-19a & in vitro & PTEN & [112] \\
\hline & $\operatorname{miR}-19 a$ & clinical & PI3K/AKT & [78] \\
\hline & miR-19a & in vitro and clinical & PTEN & [80] \\
\hline & miR-19a & in vitro and clinical & RhoB & [81] \\
\hline \multirow{3}{*}{ Prostate } & miR-19a & in vitro and clinical & CUL5 & [85] \\
\hline & miR-19a & in vitro, in vivo, and clinical & BTG1 & [86] \\
\hline & miR-19a & in vitro and clinical & VPS37A & [87] \\
\hline Myeloma & miR-19a & in vitro & PTEN/AKT/pAKT & [96] \\
\hline Ovarian & miR-19a & in vitro and clinical & PTEN & [97] \\
\hline Cervical & miR-19a & in vitro and clinical & CUL5 & [100] \\
\hline
\end{tabular}

\section{3. miR-19a as a Cancer Diagnostic and Prognostic Biomarker}

miRNAs are highly stable in biological fluids, and their expression level changes have been associated with tumor patient's prognosis or treatment response. Cancer tissues secrete circulating miRNAs into the surroundings, and they can be used as tools for cancer diagnosis and prognosis, and also for distinguishing tumor subtypes [113].

Numerous researchers have developed methods to detect miR-19a in serum, plasma, urine, and other biological fluids [114], as summarized in Figure 2. Quantitative real timePCR (qRT-PCR), microarray, and next-generation sequencing have been used to quantify the expression of circulating miRNAs [115].
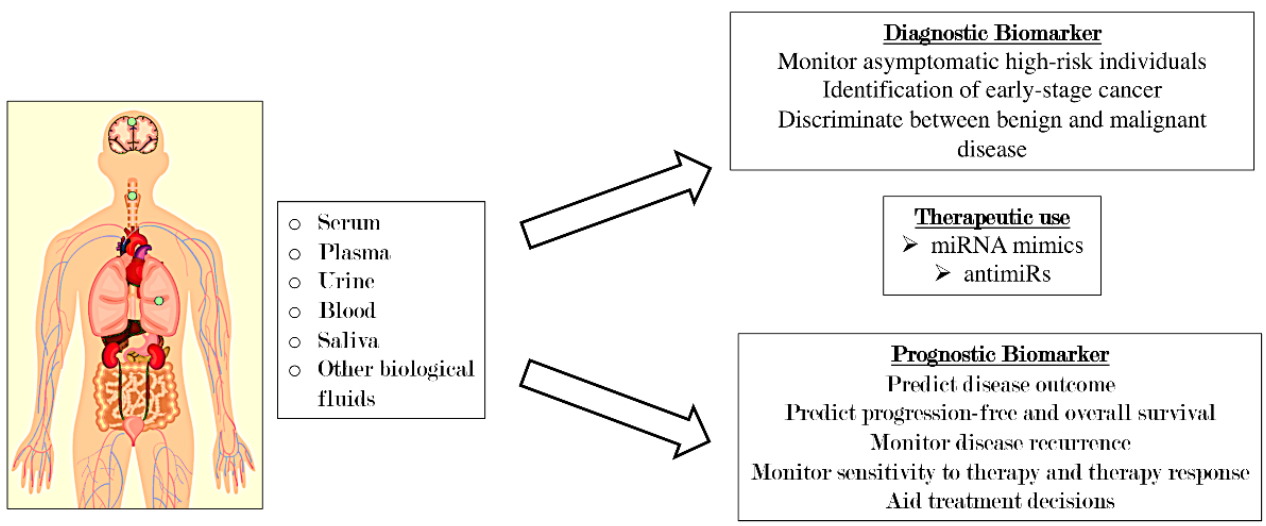

Figure 2. Promising clinical values of miR-19a for early cancer diagnosis, treatment, and prognosis.

Qiu et al. [116] analyzed 58 patients with undifferentiated lung cancer (experimental group) and 42 healthy volunteers (control group) and measured the expression levels of miR-19 in peripheral blood by qRT-PCR. They reported that miR-19 expression levels in the experimental group were significantly higher than those of the control group, indicating that miR-19 could be used as diagnostic markers for undifferentiated lung cancer.

In another study, Cheng et al. [117] evaluated circulating miR-19a-3p in plasma specimens obtained from 58 gastritis subjects, 54 patients with precancerous lesions, and 38 early gastric cancer (EGC) patients. Their results showed significant differences in the miR-19a-3p expression levels between EGC patients and gastritis subjects, highlighting that plasma miR-19a-3p could be a promising and noninvasive marker for the early diagnosis of GC.

Even though miR-19-5p is derived from the same precursor as miR-19-3p, few studies are reported in the literature on its role in tumorigenesis. Huang et al. [118] indicated the key role of miR-19-5p in the development and progression of CRC, via targeting TSP5, 
indicating that miR-19-5p could also be a useful biomarker for CRC patients, highlighting its potential implications for diagnoses and therapeutic interventions.

Other results have also been shown for osteosarcoma. Zou et al. [69] analyzed miR19a expression patterns and investigated its clinical implication in human osteosarcomas. In this study, the miR-19a expression levels in 166 self-pairs of osteosarcoma and noncancerous bone tissues were measured, by qRT-PCR, and in addition, the correlations between its expression, clinicopathological parameters, and patients' prognosis were assessed. Their results reported that miR-19a expression in osteosarcoma tissues is significantly higher than in non-cancerous bone tissues, and that high miR-19a expression levels correlate with large tumor size, advanced clinical stage, positive distant metastasis, and poor response to chemotherapy. These data suggest that miR-19a could represent a novel prognostic marker for osteosarcoma patients.

The diagnostic and prognostic value of miR-19a has also been implicated in non-small cell lung cancer (NSCLC). Lin et al. [119] have reported that high miR-19a levels in serum, detected by qRT-PCR, represented an important prognostic factor for the prediction of survival and response to chemotherapy in NSCLC patients.

Furthermore, it has also been reported that miRNAs are abundant in the exosomes, which offer them stability and play an important role in tumor growth and development [120-122]. Several tumor-specific miRNAs, entrapped in exosomes, have been found in serum, plasma, and other biological fluids, offering an easy and early cancer diagnosis. Matsumura et al. [123] reported that exosomal miR-19a expression levels in serum were significantly higher in patients with colorectal cancer (CRC) than in healthy individuals, suggesting its possible use as a prognostic biomarker for recurrence in CRC patients.

Numerous miRNAs are currently in clinical trials as biomarkers for cancer classification and progression and as prognostic tools. Moreover, several miRNAs modulators (miRNAs mimics and antimiR) have entered the clinical trials as miRNA-based therapeutic strategies to achieve tumor regression [124]. miRNA antagonists are developed to inhibit miRNAs that acquire a gain of function in cancer disease, resulting in increased expression of the tumor suppressor genes. Examples of miRNA antagonists are antimiRs [125], antagomiRs [126], and locked nucleic acids [127].

On the other hand, miRNA mimics play a contrary role in regulating the expression of target genes, re-establishing miRNAs that show a loss of function. Therefore, the miRNA mimics approach, also known as miRNA replacement therapy, could represent a novel chance of treatment for many cancer types and stages.

\section{Conclusions and Future Perspectives}

Accumulating studies have demonstrated that miR-19a is aberrantly expressed in various tumor types, and its overexpression has been associated with cell proliferation, invasion, migration, metastasis, tumor size, stage of development, and poor prognosis.

Although several hypotheses on the role of miR-19a in cancer have been proposed, its biological function and mechanism remain unclear and further analyses to determine its mechanism in tumors are necessary, as well as the correct therapeutic approach.

Furthermore, considering that circRNAs exert critical functions in tumor progression via sponging miRNAs, future research should be conducted to better elucidate possible applications in diagnostic and therapeutic oncology.

Thus, miR-19a is predicted to be a probable candidate as both a biomarker and novel therapeutic target for diagnostic and prognostic applications.

Author Contributions: A.A. and G.C. were involved in the design and intellectual concept of the study; A.F., D.G., F.E. and C.C. performed the literature search; M.C. supervised the study; and S.C., E.E. and I.P. designed the study and critically revised the manuscript. All authors have read and agreed to the published version of the manuscript.

Funding: This research received no external funding.

Conflicts of Interest: The authors declare no conflict of interest. 


\section{References}

1. Sun, W.; Shi, Q.; Zhang, H.; Yang, K.; Ke, Y.; Wang, Y.; Qiao, L. Advances in the techniques and methodologies of cancer gene therapy. Discov. Med. 2019, 27, 45-55. [PubMed]

2. Roma-Rodrigues, C.; Mendes, R.; Baptista, P.V.; Fernandes, A.R. Targeting Tumor Microenvironment for Cancer Therapy. Int. J. Mol. Sci. 2019, 20, 840. [CrossRef] [PubMed]

3. Lewandowska, A.M.; Rudzki, M.; Rudzki, S.; Lewandowski, T.; Laskowska, B. Environmental risk factors for cancer-Review paper. Ann. Agric. Environ. Med. 2019, 26, 1-7. [CrossRef]

4. Samet, J.M. Tobacco Smoking. Thorac. Surg. Clin. 2013, 23, 103-112. [CrossRef]

5. Miller, M.; Bailey, B.; Govindarajah, V.; Levin, L.; Metzger, T.; Pinney, S.M.; Leung, Y.-K.; Ho, S.-M. A community survey on knowledge of the impact of environmental and epigenetic factors on health and disease. Perspect. Public Health 2016, 136, 345-352. [CrossRef]

6. Wright, C.; Simone, N.L. Obesity and tumor growth: Inflammation, immunity, and the role of a ketogenic diet. Curr. Opin. Clin. Nutr. Metab. Care 2016, 19, 294-299. [CrossRef]

7. Sutton, S.H. Infections Associated with Solid Malignancies. Cancer Treat. Res. 2014, 161, 371-411. [CrossRef]

8. Kreuzer, M. Krebsrisiko durch ionisierende Strahlung im Niedrigdosisbereich Cancer risk from low-Dose ionizing radiation. Der. Radiol. 2017, 57, 517-518. [CrossRef]

9. Kruk, J.; Aboul-Enein, B.H.; Bernstein, J.; Gronostaj, M. Psychological Stress and Cellular Aging in Cancer: A Meta-Analysis. Oxidative Med. Cell. Longev. 2019, 2019, 1-23. [CrossRef]

10. Taş, I.; Zhou, R.; Park, S.-Y.; Yang, Y.; Gamage, C.D.; Son, Y.-J.; Paik, M.-J.; Kim, H. Inflammatory and tumorigenic effects of environmental pollutants found in particulate matter on lung epithelial cells. Toxicol. Vitro 2019, 59, 300-311. [CrossRef]

11. Grady, W.M.; Yu, M.; Markowitz, S.D. Epigenetic Alterations in the Gastrointestinal Tract: Current and Emerging Use for Biomarkers of Cancer. Gastroenterology 2021, 160, 690-709. [CrossRef]

12. Liu, Z.-B.; Ezzedine, N.E.; Eterovic, A.K.; Ensor, J.E.; Huang, H.J.; Albanell, J.; Choi, D.S.; Lluch, A.; Liu, Y.; Rojo, F.; et al. Detection of breast cancer stem cell gene mutations in circulating free DNA during the evolution of metastases. Breast Cancer Res. Treat. 2019, 178, 251-261. [CrossRef]

13. Minicozzi, P.; Walsh, P.M.; Sánchez, M.-J.; Trama, A.; Innos, K.; Marcos-Gragera, R.; Dimitrova, N.; Botta, L.; Johannesen, T.B.; Rossi, S.; et al. Is low survival for cancer in Eastern Europe due principally to late stage at diagnosis? Eur. J. Cancer 2018, 93, 127-137. [CrossRef] [PubMed]

14. Buonaguro, F.M.; Caposio, P.; Tornesello, M.L.; De Re, V.; Franco, R. Cancer Diagnostic and Predictive Biomarkers . BioMed Res. Int. 2019, 2019, 1-3. [CrossRef]

15. Lu, T.X.; Rothenberg, M.E. MicroRNA. J. Allergy Clin. Immunol. 2018, 141, 1202-1207. [CrossRef]

16. Sun, Z.; Shi, K.; Yang, S.; Liu, J.; Zhou, Q.; Wang, G.; Song, J.; Li, Z.; Zhang, Z.; Yuan, W. Effect of exosomal miRNA on cancer biology and clinical applications. Mol. Cancer 2018, 17, 1-19. [CrossRef] [PubMed]

17. Ha, M.; Kim, V.N. Regulation of microRNA biogenesis. Nat. Rev. Mol. Cell Biol. 2014, 15, 509-524. [CrossRef] [PubMed]

18. Michlewski, G.P.; Cáceres, J.F. Post-transcriptional control of miRNA biogenesis. RNA 2019, 25, 1-16. [CrossRef]

19. Stavast, C.; Erkeland, S. The Non-Canonical Aspects of MicroRNAs: Many Roads to Gene Regulation. Cells 2019, 8, 1465. [CrossRef]

20. Jonas, S.; Izaurralde, E. Towards a molecular understanding of microRNA-mediated gene silencing. Nat. Rev. Genet. 2015, 16, 421-433. [CrossRef]

21. Zhang, B.; Pan, X.; Cobb, G.P.; Anderson, T.A. microRNAs as oncogenes and tumor suppressors. Dev. Biol. 2007, 302, 1-12. [CrossRef]

22. Hubé, F.; Ulveling, D.; Sureau, A.; Forveille, S.; Francastel, C. Short intron-derived ncRNAs. Nucleic Acids Res. 2017, 45, 4768-4781. [CrossRef]

23. Bartel, D.P. MicroRNAs. Cell 2004, 116, 281-297. [CrossRef]

24. Grosshans, H.; Johnson, T.; Reinert, K.L.; Gerstein, M.; Slack, F.J. The Temporal Patterning MicroRNA let-7 Regulates Several Transcription Factors at the Larval to Adult Transition in C. elegans. Dev. Cell 2005, 8, 321-330. [CrossRef]

25. Yates, L.A.; Norbury, C.J.; Gilbert, R.J. The Long and Short of MicroRNA. Cell 2013, 153, 516-519. [CrossRef]

26. Croce, C. Introduction to the Role of MicroRNAs in Cancer Diagnosis, Prognosis, and Treatment. Cancer J. 2012, 18, 213-214. [CrossRef] [PubMed]

27. Li, X.; Teng, C.; Ma, J.; Fu, N.; Wang, L.; Wen, J.; Wang, T.-Y. miR-19 family: A promising biomarker and therapeutic target in heart, vessels and neurons. Life Sci. 2019, 232, 116651. [CrossRef] [PubMed]

28. Zhang, X.; Liu, J.; Wu, L.; Hu, X. MicroRNAs of the miR-17 92 family maintain adipose tissue macrophage homeostasis by sustaining IL-10 expression. eLife 2020, 9, e55676. [CrossRef] [PubMed]

29. Baumjohann, D.; Kageyama, R.; Clingan, J.M.; Morar, M.M.; Patel, S.; De Kouchkovsky, D.; Bannard, O.; Bluestone, J.A.; Matloubian, M.; Ansel, K.M.; et al. The microRNA cluster miR-17 92 promotes TFH cell differentiation and represses subsetinappropriate gene expression. Nat. Immunol. 2013, 14, 840-848. [CrossRef] [PubMed]

30. Lai, M.; Gonzalez-Martin, A.; Cooper, A.B.; Oda, H.; Jin, H.Y.; Shepherd, J.; He, L.; Zhu, J.; Nemazee, D.; Xiao, C. Regulation of B-cell development and tolerance by different members of the miR-17 92 family microRNAs. Nat. Commun. 2016, 7, 12207. [CrossRef] [PubMed] 
31. Olive, V.; Bennett, M.J.; Walker, J.C.; Ma, C.; Jiang, I.; Cordon-Cardo, C.; Li, Q.-J.; Lowe, S.W.; Hannon, G.J.; He, L. miR-19 is a key oncogenic component of mir-17-92. Genes Dev. 2009, 23, 2839-2849. [CrossRef] [PubMed]

32. Liang, Z.; Li, Y.; Huang, K.; Wagar, N.; Shim, H. Regulation of miR-19 to breast cancer chemoresistance through targeting PTEN. Pharm. Res. 2011, 28, 3091-3100. [CrossRef]

33. Xing, S.; Qu, Y.; Li, C.; Huang, A.; Tong, S.; Wu, C.; Fan, K. Deregulation of lncRNA-AC078883.3 and microRNA-19a is involved in the development of chemoresistance to cisplatin via modulating signaling pathway of PTEN/AKT. J. Cell. Physiol. 2019, 234, 22657-22665. [CrossRef]

34. Jiang, X.-M.; Yu, X.-N.; Liu, T.-T.; Zhu, H.-R.; Shi, X.; Bilegsaikhan, E.; Guo, H.-Y.; Song, G.-Q.; Weng, S.-Q.; Huang, X.-X.; et al. microRNA-19a-3p promotes tumor metastasis and chemoresistance through the PTEN/Akt pathway in hepatocellular carcinoma. Biomed. Pharmacother. 2018, 105, 1147-1154. [CrossRef]

35. Maji, S.; Panda, S.; Samal, S.K.; Shriwas, O.; Rath, R.; Pellecchia, M.; Emdad, L.; Das, S.K.; Fisher, P.B.; Dash, R. Bcl-2 Antiapoptotic Family Proteins and Chemoresistance in Cancer. Adv. Cancer Res. 2018, 137, 37-75. [CrossRef]

36. Wang, F.; Li, T.; Zhang, B.; Li, H.; Wu, Q.; Yang, L.; Nie, Y.; Wu, K.; Shi, Y.; Fan, D. MicroRNA-19a/b regulates multidrug resistance in human gastric cancer cells by targeting PTEN. Biochem. Biophys. Res. Commun. 2013, 434, 688-694. [CrossRef] [PubMed]

37. Panda, A.C. Circular RNAs Act as miRNA Sponges. Adv. Exp. Med. Biol. 2018, 1087, 67-79. [CrossRef]

38. Liu, Z.; Zhou, Y.; Liang, G.; Ling, Y.; Tan, W.; Tan, L.; Andrews, R.; Zhong, W.; Zhang, X.; Song, E.; et al. Circular RNA hsa_circ_001783 regulates breast cancer progression via sponging miR-200c-3p. Cell Death Dis. 2019, 10, 1-14. [CrossRef]

39. Tang, Q.; Chen, Z.; Zhao, L.; Xu, H. Circular RNA hsa_circ_0000515 acts as a miR-326 sponge to promote cervical cancer progression through up-regulation of ELK1. Aging 2019, 11, 9982-9999. [CrossRef]

40. Qin, N.; Tong, G.-F.; Sun, L.-W.; Xu, X.-L. Long Noncoding RNA MEG3 Suppresses Glioma Cell Proliferation, Migration, and Invasion by Acting as a Competing Endogenous RNA of miR-19a. Oncol. Res. Featur. Preclin. Clin. Cancer Ther. 2017, 25, 1471-1478. [CrossRef]

41. Chen, C.-Y.; Chen, J.; He, L.; Stiles, B.L. PTEN: Tumor Suppressor and Metabolic Regulator. Front. Endocrinol. 2018, 9, 338. [CrossRef] [PubMed]

42. Murugan, A.K. Special issue: PI3K/Akt signaling in human cancer. Semin. Cancer Biol. 2019, 59, 1-2. [CrossRef] [PubMed]

43. Deng, J.; Bai, X.; Feng, X.; Ni, J.; Beretov, J.; Graham, P.; Li, Y. Inhibition of PI3K/Akt/mTOR signaling pathway alleviates ovarian cancer chemoresistance through reversing epithelial-mesenchymal transition and decreasing cancer stem cell marker expression. BMC Cancer 2019, 19, 1-12. [CrossRef] [PubMed]

44. Chen, Q.; Guo, W.; Zhang, Y.; Wu, Y.; Xiang, J. MiR-19a promotes cell proliferation and invasion by targeting RhoB in human glioma cells. Neurosci. Lett. 2016, 628, 161-166. [CrossRef] [PubMed]

45. Lv, T.; Miao, Y.; Xu, T.; Sun, W.; Sang, Y.; Jia, F.; Zhang, X. Circ-EPB41L5 regulates the host gene EPB41L5 via sponging miR-19a to repress glioblastoma tumorigenesis. Aging 2020, 12, 318-339. [CrossRef] [PubMed]

46. Thomas, P.; Pranatharthi, A.; Ross, C.; Srivastava, S. RhoC: A fascinating journey from a cytoskeletal organizer to a Cancer stem cell therapeutic target. J. Exp. Clin. Cancer Res. 2019, 38, 1-11. [CrossRef]

47. Guan, X.; Chen, S.; Zhao, Y. The role of RhoC in malignant tumor invasion, metastasis and targeted therapy. Histol. Histopathol. 2017, 33, 255-260.

48. Hoeppner, L.H.; Sinha, S.; Wang, Y.; Bhattacharya, R.; Dutta, S.; Gong, X.; Bedell, V.M.; Suresh, S.; Chun, C.; Ramchandran, R.; et al. RhoC maintains vascular homeostasis by regulating VEGF-induced signaling in endothelial cells. J. Cell Sci. 2015, 128, 3556-3568. [CrossRef]

49. Xu, X.-L.; Jiang, Y.-H.; Feng, J.-G.; Su, D.; Chen, P.-C.; Mao, W.-M. MicroRNA-17, MicroRNA-18a, and MicroRNA-19a Are Prognostic Indicators in Esophageal Squamous Cell Carcinoma. Ann. Thorac. Surg. 2014, 97, 1037-1045. [CrossRef]

50. Plum, P.S.; Warnecke-Eberz, U.; Drebber, U.; Chon, S.-H.; Alakus, H.; Hölscher, A.H.; Quaas, A.; Bruns, C.J.; Gockel, I.; Lorenz, D.; et al. Upregulation of miR-17-92 cluster is associated with progression and lymph node metastasis in oesophageal adenocarcinoma. Sci. Rep. 2019, 9, 1-11. [CrossRef]

51. Yuan, J.; Tan, L.; Yin, Z.; Zhu, W.; Tao, K.; Wang, G.; Shi, W.; Gao, J. MIR17HG-miR-18a/19a axis, regulated by interferon regulatory factor-1, promotes gastric cancer metastasis via Wnt/ $\beta$-catenin signalling. Cell Death Dis. 2019, 10, 1-16. [CrossRef]

52. Zhu, Y.; Li, L.; Hou, D.; Ouyang, Y.; Guo, X.; Wang, Y.; Li, J.; Gong, K. MicroRNA-19a regulates the proliferation, migration and invasion of human gastric cancer cells by targeting CUL. Arch. Biochem. Biophys. 2019, 662, 93-100. [CrossRef]

53. Rossi, A.F.T.; Contiero, J.C.; Manoel-Caetano, F.D.S.; Severino, F.E.; Silva, A.E. Up-regulation of tumor necrosis factor- $\alpha$ pathway survival genes and of the receptor TNFR2 in gastric cancer. World J. Gastrointest. Oncol. 2019, 11, 281-294. [CrossRef]

54. Qin, S.; Ai, F.; Ji, W.-F.; Rao, W.; Zhang, H.-C.; Yao, W.-J. miR-19a Promotes Cell Growth and Tumorigenesis through Targeting SOCS1 in Gastric Cancer. Asian Pac. J. Cancer Prev. 2013, 14, 835-840. [CrossRef]

55. Liu, H.-N.; Wu, H.; Tseng, Y.-J.; Chen, Y.-J.; Zhang, D.-Y.; Zhu, L.; Dong, L.; Shen, X.-Z.; Liu, T.-T. Serum microRNA signatures and metabolomics have high diagnostic value in gastric cancer. BMC Cancer 2018, 18, 1-11. [CrossRef]

56. Sierzega, M.; Kaczor, M.; Kolodziejczyk, P.; Kulig, J.; Sanak, M.; Richter, P. Evaluation of serum microRNA biomarkers for gastric cancer based on blood and tissue pools profiling: The importance of miR-21 and miR-331. Br. J. Cancer 2017, 117, $266-273$. [CrossRef]

57. Liu, Y.; Liu, R.; Yang, F.; Cheng, R.; Chen, X.; Cui, S.; Gu, Y.; Sun, W.; You, C.; Liu, Z.; et al. miR-19a promotes colorectal cancer proliferation and migration by targeting TIA. Mol. Cancer 2017, 16, 1-17. [CrossRef] 
58. Baik, S.H.; Lee, J.; Lee, Y.-S.; Jang, J.-Y.; Kim, C.-W. ANT2 shRNA downregulates miR-19a and miR-96 through the PI3K/Akt pathway and suppresses tumor growth in hepatocellular carcinoma cells. Exp. Mol. Med. 2016, 48, e222. [CrossRef]

59. Tan, Y.; Yin, H.; Zhang, H.; Fang, J.; Zheng, W.; Li, D.; Li, Y.; Cao, W.; Sun, C.; Liang, Y.; et al. Sp1-driven up-regulation of miR-19a decreases RHOB and promotes pancreatic cancer. Oncotarget 2015, 6, 17391-17403. [CrossRef]

60. Li, H.; Jin, Y.; Hu, Y.; Jiang, L.; Liu, F.; Zhang, Y.; Hao, Y.; Chen, S.; Wu, X.; Liu, Y. The PLGF/c-MYC/miR-19a axis promotes metastasis and stemness in gallbladder cancer. Cancer Sci. 2018, 109, 1532-1544. [CrossRef]

61. Li, D.; Liu, K.; Li, Z.; Wang, J.; Wang, X. miR-19a and miR-424 target TGFBR3 to promote epithelial-to-mesenchymal transition and migration of tongue squamous cell carcinoma cells. Cell Adhes. Migr. 2017, 12, 236-246. [CrossRef]

62. Wu, T.-Y.; Zhang, T.-H.; Qu, L.-M.; Feng, J.-P.; Tian, L.-L.; Zhang, B.-H.; Li, D.-D.; Sun, Y.-N.; Liu, M. MiR-19a is correlated with prognosis and apoptosis of laryngeal squamous cell carcinoma by regulating TIMP-2 expression. Int. J. Clin. Exp. Pathol. 2013, 7, 56-63.

63. Marioni, G.; Agostini, M.; Cappellesso, R.; Bedin, C.; Ottaviano, G.; Marchese-Ragona, R.; Lovato, A.; Cacco, T.; Giacomelli, L.; Nitti, D.; et al. miR-19a and SOCS-1 expression in the differential diagnosis of laryngeal (glottic) verrucous squamous cell carcinoma. J. Clin. Pathol. 2015, 69, 415-421. [CrossRef]

64. Hu, W.; Jin, P.; Ding, C.; Liu, W. miR-19a/b modulates lung cancer cells metastasis through suppression of MXD1 expression. Oncol. Lett. 2016, 12, 1901-1905. [CrossRef]

65. Cao, X.; Lai, S.; Hu, F.; Li, G.; Wang, G.; Luo, X.; Fu, X.; Hu, J. miR-19a contributes to gefitinib resistance and epithelial mesenchymal transition in non-small cell lung cancer cells by targeting c-Met. Sci. Rep. 2017, 7, 2939. [CrossRef]

66. Gu, Y.; Liu, S.; Zhang, X.; Chen, G.; Liang, H.; Yu, M.; Liao, Z.; Zhou, Y.; Zhang, C.-Y.; Wang, T.; et al. Oncogenic miR-19a and miR-19b co-regulate tumor suppressor MTUS1 to promote cell proliferation and migration in lung cancer. Protein Cell 2017, 8, 455-466. [CrossRef]

67. Lu, S.; Kong, H.; Hou, Y.; Ge, D.; Huang, W.; Ou, J.; Yang, D.; Zhang, L.; Wu, G.; Song, Y.; et al. Two plasma microRNA panels for diagnosis and subtype discrimination of lung cancer. Lung Cancer 2018, 123, 44-51. [CrossRef]

68. Peng, Y.; Huang, D.; Ma, K.; Deng, X.; Shao, Z. MiR-19a as a prognostic indicator for cancer patients: A meta-Analysis. Biosci. Rep. 2019, 39. [CrossRef]

69. Zou, P.; Ding, J.; Fu, S. Elevated expression of microRNA-19a predicts a poor prognosis in patients with osteosarcoma. Pathol. Res. Pract. 2017, 213, 194-198. [CrossRef] [PubMed]

70. Huang, G.; Nishimoto, K.; Zhou, Z.; Hughes, D.; Kleinerman, E.S. miR-20a Encoded by the miR-17-92 Cluster Increases the Metastatic Potential of Osteosarcoma Cells by Regulating Fas Expression. Cancer Res. 2012, 72, 908-916. [CrossRef]

71. Zou, Q.; Xiao, X.; Liang, Y.; Peng, L.; Guo, Z.; Li, W.; Yu, W. miR-19a-mediated downregulation of RhoB inhibits the dephosphorylation of AKT1 and induces osteosarcoma cell metastasis. Cancer Lett. 2018, 428, 147-159. [CrossRef]

72. Calabrese, G.; Dolcimascolo, A.; Torrisi, F.; Zappalà, A.; Gulino, R.; Parenti, R. MiR-19a Overexpression in FTC-133 Cell Line Induces a More De-Differentiated and Aggressive Phenotype. Int. J. Mol. Sci. 2018, 19, 3944. [CrossRef]

73. Calabrese, G.; Dolcimascolo, A.; Caruso, G.; Forte, S. miR-19a Is Involved in Progression and Malignancy of Anaplastic Thyroid Cancer Cells. OncoTargets Ther. 2019, 12, 9571-9583. [CrossRef]

74. Das, P.; Asha, S.; Abe, I.; Islam, F.; Lam, A. Roles of Non-Coding RNAs on Anaplastic Thyroid Carcinomas. Cancers 2020, $12,3159$. [CrossRef]

75. Ma, Q.; Peng, Z.; Wang, L.; Li, Y.; Wang, K.; Zheng, J.; Liang, Z.; Liu, T. miR-19a correlates with poor prognosis of clear cell renal cell carcinoma patients via promoting cell proliferation and suppressing PTEN/SMAD4 expression. Int. J. Oncol. 2016, 49, 2589-2599. [CrossRef]

76. Niu, S.; Ma, X.; Zhang, Y.; Liu, Y.-N.; Chen, X.; Gong, H.; Yao, Y.; Liu, K.; Zhang, X. MicroRNA-19a and microRNA-19b promote the malignancy of clear cell renal cell carcinoma through targeting the tumor suppressor RhoB. PLoS ONE 2018, 13, e0192790. [CrossRef]

77. Ge, Y.-Z.; Xin, H.; Lu, T.-Z.; Xu, Z.; Yu, P.; Zhao, Y.-C.; Li, M.-H.; Zhao, Y.; Zhong, B.; Xu, X.; et al. MicroRNA expression profiles predict clinical phenotypes and prognosis in chromophobe renal cell carcinoma. Sci. Rep. 2015, 5, 10328. [CrossRef] [PubMed]

78. Calderaro, J.; Rebouissou, S.; De Koning, L.; Masmoudi, A.; Hérault, A.; Dubois, T.; Maille, P.; Soyeux, P.; Sibony, M.; De La Taille, A.; et al. PI3K/AKT pathway activation in bladder carcinogenesis. Int. J. Cancer 2013, 134, 1776-1784. [CrossRef]

79. Mearini, E.; Poli, G.; Cochetti, G.; Boni, A.; Egidi, M.G.; Brancorsini, S. Expression of urinary miRNAs targeting NLRs inflammasomes in bladder cancer. OncoTargets Ther. 2017, 10, 2665-2673. [CrossRef]

80. Feng, Y.; Liu, J.; Kang, Y.; He, Y.; Liang, S.B.; Yang, P.; Yu, Z. miR-19a acts as an oncogenic microRNA and is up-Regulated in bladder cancer. J. Exp. Clin. Cancer Res. 2014, 33, 67. [CrossRef]

81. Li, Z.; Li, Y.; Wang, Y. miR-19a promotes invasion and epithelial to mesenchymal transition of bladder cancer cells by targeting RhoB. J. BUON 2019, 24, 797-804. [PubMed]

82. Yin, X.-H.; Jin, Y.-H.; Cao, Y.; Wong, Y.; Weng, H.; Sun, C.; Deng, J.-H.; Zeng, X.-T. Development of a 21-miRNA Signature Associated With the Prognosis of Patients With Bladder Cancer. Front. Oncol. 2019, 9, 729. [CrossRef] [PubMed]

83. Ottman, R.; Levy, J.; Grizzle, W.E.; Chakrabarti, R. The other face of miR-17-92a cluster, exhibiting tumor suppressor effects in prostate cancer. Oncotarget 2016, 7, 73739-73753. [CrossRef] [PubMed]

84. Lakshmanan, V.-K.; Ojha, S.; Jung, Y.D. A modern era of personalized medicine in the diagnosis, prognosis, and treatment of prostate cancer. Comput. Biol. Med. 2020, 126, 104020. [CrossRef] 
85. Wang, Y.; Hu, J.; Qi, G.; Wang, S.; Gao, J. miR-19a promotes the metastasis and EMT through CUL5 in prostate cancer cell line PC. J. BUON 2020, 25, 2028-2035.

86. Lu, K.; Liu, C.; Tao, T.; Zhang, X.; Zhang, L.; Sun, C.; Wang, Y.; Chen, S.; Xu, B.; Chen, M. MicroRNA-19a regulates proliferation and apoptosis of castration-resistant prostate cancer cells by targeting BTG. FEBS Lett. 2015, 589, 1485-1490. [CrossRef]

87. Fu, F.; Wan, X.; Wang, D.; Kong, Z.; Zhang, Y.; Huang, W.; Wang, C.; Wu, H.; Li, Y. MicroRNA-19a acts as a prognostic marker and promotes prostate cancer progression via inhibiting VPS37A expression. Oncotarget 2018, 9, 1931-1943. [CrossRef]

88. Stuopelytė, K.; Daniūnaitè, K.; Jankevičius, F.; Jarmalaitè, S. Detection of miRNAs in urine of prostate cancer patients. Medicina 2016, 52, 116-124. [CrossRef]

89. Norouzi, S.; Majeed, M.; Pirro, M.; Generali, D.; Sahebkar, A. Curcumin as an Adjunct Therapy and microRNA Modulator in Breast Cancer. Curr. Pharm. Des. 2018, 24, 171-177. [CrossRef]

90. Sochor, M.; Basova, P.; Pesta, M.; Dusilkova, N.; Bartos, J.; Burda, P.; Pospisil, V.; Stopka, T. Oncogenic MicroRNAs: miR-155, miR-19a, miR-181b, and miR-24 enable monitoring of early breast cancer in serum. BMC Cancer 2014, 14, 448. [CrossRef]

91. Kawaguchi, T.; Yan, L.; Qi, Q.; Peng, X.; Edge, S.B.; Young, J.; Yao, S.; Liu, S.; Otsuji, E.; Takabe, K. Novel MicroRNA-Based Risk Score Identified by Integrated Analyses to Predict Metastasis and Poor Prognosis in Breast Cancer. Ann. Surg. Oncol. 2018, 25, 4037-4046. [CrossRef] [PubMed]

92. Alunni-Fabbroni, M.; on Behalf of the SUCCESS Study Group; Majunke, L.; Trapp, E.K.; Tzschaschel, M.; Mahner, S.; Fasching, P.A.; Fehm, T.; Schneeweiss, A.; Beck, T.; et al. Whole blood microRNAs as potential biomarkers in post-operative early breast cancer patients. BMC Cancer 2018, 18, 1-12. [CrossRef] [PubMed]

93. Ouchida, M.; Kanzaki, H.; Ito, S.; Hanafusa, H.; Jitsumori, Y.; Tamaru, S.; Shimizu, K. Novel Direct Targets of miR-19a Identified in Breast Cancer Cells by a Quantitative Proteomic Approach. PLoS ONE 2012, 7, e44095. [CrossRef] [PubMed]

94. Tagawa, H.; Ikeda, S.; Sawada, K. Role of micro RNA in the pathogenesis of malignant lymphoma. Cancer Sci. 2013, 104, 801-809. [CrossRef] [PubMed]

95. Lv, H.; Wu, X.; Ma, G.; Sun, L.; Meng, J.; Song, X.; Zhang, J. An integrated bioinformatical analysis of miR-19a target genes in multiple myeloma. Exp. Ther. Med. 2017, 14, 4711-4720. [CrossRef]

96. Zhang, X.; Chen, Y.; Zhao, P.; Zang, L.; Zhang, Z.; Wang, X. MicroRNA-19a functions as an oncogene by regulating PTEN/AKT/pAKT pathway in myeloma. Leuk. Lymphoma 2016, 58, 932-940. [CrossRef]

97. Wang, Y.; Zhao, S.; Zhu, L.; Zhang, Q.; Ren, Y. MiR-19a negatively regulated the expression of PTEN and promoted the growth of ovarian cancer cells. Gene 2018, 670, 166-173. [CrossRef]

98. Wahab, N.A.; Othman, Z.; Nasri, N.W.M.; Mokhtar, M.H.; Ibrahim, S.F.; Hamid, A.A.; Ali, R.A.R.; Mokhtar, N.M. Inhibition of miR-141 and miR-200a Increase DLC-1 and ZEB2 Expression, Enhance Migration and Invasion in Metastatic Serous Ovarian Cancer. Int. J. Environ. Res. Public Health 2020, 17, 2766. [CrossRef]

99. Wang, Y.; Wang, Y.; Zhong, W.; Gulina, K. Correlation between miR-19a inhibition and radiosensitivity in SiHa cervical cancer cells. J. BUON 2017, 22, 1505-1508.

100. Xu, X.-M.; Wang, X.-B.; Chen, M.-M.; Liu, T.; Li, Y.-X.; Jia, W.-H.; Liu, M.; Li, X.; Tang, H. MicroRNA-19a and -19b regulate cervical carcinoma cell proliferation and invasion by targeting CUL. Cancer Lett. 2012, 322, 148-158. [CrossRef]

101. Sionov, R.V.; Vlahopoulos, S.A.; Granot, Z. Regulation of Bim in Health and Disease. Oncotarget 2015, 6, 23058-23134. [CrossRef]

102. Shukla, S.; Saxena, S.; Singh, B.K.; Kakkar, P. BH3-only protein BIM: An emerging target in chemotherapy. Eur. J. Cell Biol. 2017, 96, 728-738. [CrossRef] [PubMed]

103. Akiyama, T.; Tanaka, S. Bim: Guardian of Tissue Homeostasis and Critical Regulator of the Immune System, Tumorigenesis and Bone Biology. Arch. Immunol. Ther. Exp. 2011, 59, 277-287. [CrossRef]

104. Zhang, L.-N.; Li, J.-Y.; Xu, W. A review of the role of Puma, Noxa and Bim in the tumorigenesis, therapy and drug resistance of chronic lymphocytic leukemia. Cancer Gene Ther. 2012, 20, 1-7. [CrossRef]

105. Chen, L.; Li, C.; Zhang, R.; Gao, X.; Qu, X.; Zhao, M.; Qiao, C.; Xu, J.; Li, J. miR-17-92 cluster microRNAs confers tumorigenicity in multiple myeloma. Cancer Lett. 2011, 309, 62-70. [CrossRef]

106. Shuang, T.; Shi, C.; Chang, S.; Wang, M.; Bai, C.H. Downregulation of miR-17 92 Expression Increase Paclitaxel Sensitivity in Human Ovarian Carcinoma SKOV3-TR30 Cells via BIM Instead of PTEN. Int. J. Mol. Sci. 2013, 14, 3802-3816. [CrossRef] [PubMed]

107. Fang, L.-L.; Wang, X.-H.; Sun, B.-F.; Zhang, X.-D.; Zhu, X.-H.; Yu, Z.-J.; Luo, H. Expression, regulation and mechanism of action of the miR-17-92 cluster in tumor cells (Review). Int. J. Mol. Med. 2017, 40, 1624-1630. [CrossRef]

108. Qian, Y.; Liu, Z.; Zhang, Z.; Levenson, A.S.; Li, K. Pterostilbene increases PTEN expression through the targeted downregulation of microRNA-19a in hepatocellular carcinoma. Mol. Med. Rep. 2018, 17, 5193-5201. [CrossRef]

109. Liu, R.; Shen, L.; Qu, N.; Zhao, X.; Wang, J.; Geng, J. MiR-19a Promotes Migration And Invasion By Targeting RHOB in Osteosarcoma. OncoTargets Ther. 2019, 12, 7801-7808. [CrossRef]

110. Zhao, D.; Chen, Y.; Chen, S.; Zheng, C.; Hu, J.; Luo, S. MiR-19a regulates the cell growth and apoptosis of osteosarcoma stem cells by targeting PTEN. Tumor Biol. 2017, 39, 1010428317705341. [CrossRef]

111. Li, X.; Sun, X.-H.; Xu, H.-Y.; Pan, H.-S.; Liu, Y.; He, L. Circ_ORC2 enhances the regulatory effect of miR-19a on its target gene PTEN to affect osteosarcoma cell growth. Biochem. Biophys. Res. Commun. 2019, 514, 1172-1178. [CrossRef] [PubMed]

112. Cao, Y.; Yu, S.-L.; Wang, Y.; Guo, G.-Y.; Ding, Q.; An, R.-H. MicroRNA-dependent regulation of PTEN after arsenic trioxide treatment in bladder cancer cell line T. Tumor Biol. 2010, 32, 179-188. [CrossRef] [PubMed] 
113. Yu, D.-C.; Li, Q.-G.; Ding, X.-W.; Ding, Y.-T. Circulating MicroRNAs: Potential Biomarkers for Cancer. Int. J. Mol. Sci. 2011, 12, 2055-2063. [CrossRef] [PubMed]

114. Kamal, N.N.S.B.N.M.; Shahidan, W.N.S. Non-Exosomal and Exosomal Circulatory Micrornas: Which Are More Valid as Biomarkers? Front. Pharmacol. 2020, 10, 1500. [CrossRef]

115. Bellingham, S.A.; Coleman, B.M.; Hill, A.F. Small RNA deep sequencing reveals a distinct miRNA signature released in exosomes from prion-infected neuronal cells. Nucleic Acids Res. 2012, 40, 10937-10949. [CrossRef]

116. Qiu, F.; Gu, W.-G.; Li, C.; Nie, S.-L.; Yu, F. Analysis on expression level and diagnostic value of miR-19 and miR-21 in peripheral blood of patients with undifferentiated lung cancer. Eur. Rev. Med Pharmacol. Sci. 2018, 22, 8367-8373. [PubMed]

117. Cheng, J.; Yang, A.; Cheng, S.; Feng, L.; Wu, X.; Lu, X.; Zu, M.; Cui, J.; Yu, H.; Zou, L. Circulating miR-19a-3p and miR-483-5p as Novel Diagnostic Biomarkers for the Early Diagnosis of Gastric Cancer. Med Sci. Monit. 2020, 26, e923444. [CrossRef]

118. Huang, C.; Luo, H. miR-19-5p enhances tumorigenesis in human colorectal cancer cells by targeting TSPYL5. DNA Cell Biol. 2018, 37, 23-30. [CrossRef] [PubMed]

119. Lin, Q.; Chen, T.; Lin, Q.; Lin, G.; Lin, J.; Chen, G.; Guo, L. Serum miR-19a expression correlates with worse prognosis of patients with non-small cell lung cancer. J. Surg. Oncol. 2013, 107, 767-771. [CrossRef]

120. Lau, C.; Kim, Y.; Chia, D.; Spielmann, N.; Eibl, G.; Elashoff, D.; Wei, F.; Lin, Y.-L.; Moro, A.; Grogan, T.; et al. Role of Pancreatic Cancer-derived Exosomes in Salivary Biomarker Development. J. Biol. Chem. 2013, 288, 26888-26897. [CrossRef]

121. Milane, L.; Singh, A.; Mattheolabakis, G.; Suresh, M.; Amiji, M.M. Exosome mediated communication within the tumor microenvironment. J. Control. Release 2015, 219, 278-294. [CrossRef] [PubMed]

122. Wang, Q.Z.; Xu, W.; Habib, N.; Xu, R. Potential Uses of MicroRNA in Lung Cancer Diagnosis, Prognosis, and Therapy. Curr. Cancer Drug Targets 2009, 9, 572-594. [CrossRef] [PubMed]

123. Matsumura, T.; Sugimachi, K.; Iinuma, H.; Takahashi, Y.; Kurashige, J.; Sawada, G.; Ueda, M.; Uchi, R.; Ueo, H.; Takano, Y.; et al. Exosomal microRNA in serum is a novel biomarker of recurrence in human colorectal cancer. Br. J. Cancer 2015, 113, 275-281. [CrossRef]

124. Bader, A.G.; Brown, D.L.; Stoudemire, J.; Lammers, P.J. Developing therapeutic microRNAs for cancer. Gene Ther. 2011, 18, 1121-1126. [CrossRef] [PubMed]

125. Rupaimoole, R.; Slack, F.J. MicroRNA therapeutics: Towards a new era for the management of cancer and other diseases. Nat. Rev. Drug Discov. 2017, 16, 203-222. [CrossRef]

126. Innao, V.; Allegra, A.; Pulvirenti, N.; Allegra, A.G.; Musolino, C. Therapeutic potential of antagomiRs in haematological and oncological neoplasms. Eur. J. Cancer Care 2020, 29, e13208. [CrossRef]

127. Veedu, R.N.; Wengel, J. Locked Nucleic Acids: Promising Nucleic Acid Analogs for Therapeutic Applications. Chem. Biodivers. 2010, 7, 536-542. [CrossRef] [PubMed] 